\title{
IMPLIKASI HUKUM KEPUTUSAN MK 46/PUU-VIII/2010 TERHADAP HAK WARIS ANAK LUAR KAWIN
}

\author{
Arsad Hidayat Jurjanih \\ Program Doktoral UIN Sunan Gunung Djati Bandung \\ arsyadhidayat108@gmail.com
}

\begin{abstract}
Abstrak
Permasalahan yang diteliti adalah bagaimana hubungan anak luar perkawinan berdasarkan hukum Islam dan KUHPerdata, serta apa persamaan dan perbedaan status hukum anak yang lahir di luar perkawinan berdasarkan hukum Islam dan KUHPerdata. Adapun tujuan penelitian ini adalah untuk mengetahui bagaimana hubungan keperdataan anak luar perkawinan dengan kedua orang tuanya berdasarkan hukum Islam dan KUHPerdata dan untuk mengetahui persamaan dan perbedaan anakyang lahir di luar perkawinan berdasarkan hukum Islam dan KUHPerdata. Adapaun metode penelitian yang digunakan yaitu metode normatif. Adapun hasil penelitian dalam hukum Islam anak luar kawin hanya mempunyai hubungan keperdataan dengan ibu dan keluarga ibunya dan dalam KUHPerdata anak luar kawin akan mempunyai hubungan keperdataan dengan ayah dan ibunya setelah ada pengesahan dan pengakuan dari ayah dan ibunya. Putusan Mahkamah Konstitusi Nomor 46/PUU-VIII/2010 berimplikasi terhadap perubahan nilai-nilai dalam masyarakat mengenai status dan hak-hak anak terhadap anak luar kawin. Putusan Mahkamah Konstitusi tersebut di satu sisi melindungi hak-hak anak luar kawin, karena dengan putusan tersebut maka anak luar kawin mempunyai hak untuk mewaris, mendapatkan nafkah dan perwalian dari ayah biologisnya. Akan tetapi disisi lain, putusan tersebut terkesan melemahkan fungsi dan menyebabkan lembaga perkawinan menjadi kurang relevan
\end{abstract}

Kata kunci: hubungan keperdataan, anak luar kawin, putusan mahkamah konstitusi

\begin{abstract}
The problem under study is how the relationship between children born out of wedlock is based on Islamic law and the Civil Code, and what are the similarities and differences in the legal status of children born out of wedlock based on Islamic law and the Civil Code. The purpose of this study is to find out how the civil relationship between children born out of wedlock and their parents is based on Islamic law and the Civil Code and to find out the similarities and differences of children born out of wedlock based on Islamic law and the Civil Code. The research method used is the normative method. The results of research in Islamic law that children out of wedlock only have a civil relationship with their mother and mother's family and in the Civil Code, children outside of marriage will have a civil relationship with their father and mother after there is ratification and acknowledgment from their father and mother. The decision of the Constitutional Court Number 46/PUU-VIII/2010 has implications for changes in values in society regarding the status and rights of children to children outside of marriage. On the one hand, the decision of the Constitutional Court protects the rights of illegitimate children, because with this decision, illegitimate children have the right to inherit, earn a living and guardianship from their biological father. However, on the other hand, the decision seems to weaken the function and cause the institution of marriage to become less relevant
\end{abstract}

Keywords: civil relations, children out of wedlock, decisions of the constitutional court 


\section{A. Pendahuluan}

Anak merupakan karunia sekaligus amanat dari Allah SWT, yang senantiasa harus dijaga karena dalam dirinya melekat harkat, martabat, dan hak-hak sebagai manusia yang harus dijunjung tinggi. Bagi orang tua anak merupakan karunia Allah yang tak ternilai, ia sebagai penyejuk hati, penerus keturunan dan cita-cita ideal orang tua, dan dari sisi kehidupan berbangsa dan bernegara, anak adalah masa depan bangsa dan generasi penerus cita-cita bangsa. Pada Pasal 28B ayat (2) UUD 1945 dinyatakan, "Setiap anak berhak atas kelangsungan hidup, tumbuh, dan berkembang, berpartisipasi serta berhak atas perlindungan dari tindak kekerasan dan diskriminasi serta hak sipil dan kebebasan".

Secara rinci hak-hak anak disebutkan dalam Pasal 5 sampai dengan Pasal 18 UU Nomor 23 Tahun 2002 Tentang Perlindungan Anak sebagaimana telah diubah dengan UU Nomor 35 Tahun 2014, yang antara lain "anak berhak mengetahui orang tuanya". Mengetahui orang tuanya berkaitan dengan asal-usul anak. Asal usul anak ini dapat dibuktikan antara lain dengan akta kelahiran. Bagi anak yang lahir dari perkawinan yang sah untuk mendapatkan akta kelahiran tidaklah sulit, tinggal diurus sesuai dengan prosedur dan persyaratan yang ditentukan, sehingga anak yang lahir dari perkawinan yang sah mendapatkan perlindungan yang sempurna berkaitan dengan segala akibat hukumnya. Namun bagi anak yang dilahirkan dari perkawinan tidak yang sah, untuk mengetahui asal-usul anak harus melalui putusan Pengadilan. Dan tidak semua permohonan asal-usul anak dikabulkan oleh Pengadilan, karena Pengadilan hanya mengabulkan permohonan asal-usul anak, jika dapat dibuktikan dan beralasan hukum. Hal ini tentunya menjadi permasalahan tersendiri untuk anak yang lahir di luar perkawinan yang resmi yang mestinya tidak terjadi. Toh mereka juga pastinya klo ditanya tidak akan menginginkan kondisi demikian.

Namun dengan turunnya putusan dari Mahkamah Konstitusi Nomor 46/PUUVIII/2010 tentang kedudukan anak luar kawin, ada secerca harapan buat anak yang dilahirkan di luar perkawinan tidak hanya mempunyai hubungan perdata dengan ibunya dan keluarga ibunya akan tetapi juga memiliki hubungan keperdataan dengan ayahnya yang dapat selama dapat dibuktikan berdasarkan ilmu pengetahuan dan teknologi dan/atau alat bukti lain yang menurut hukum mempunyai hubungan darah, termasuk hubungan perdata dengan keluarga ayahnya.

Dalam penelitian ini, penulis akan focus membahas permsalahan yang dihadapi anak luar kawin baik dalam kacamata hukum Islam maupun hukum perdata yang berlaku di Indonesia serta implikasi hukum yang muncul setelah turunnya putusan dari Mahkamah Konstitusi Nomor 46/PUUVIII/2010 terhadap permasalahan yang dihadapi nak luar kawin khususnya dalam pembuatan akta kelahiran dan akta waris.

\section{B. Pembahasan}

\section{Pengertian Anak Luar Kawin}

Secara umum pengertian anak atau keturunan adalah anak-anak yang dilahirkan atau keturunan yang menimbulkan hubungan darah yaitu hubungan antara orang yang satu dengan orang tua atau leluhurnya ke atas. Pasal 42 Undang-undang No. 1 Tahun 1974, anak yang sah adalah anak yang dilahirkan dalam atau sebagai akibat perkawinan yang sah. ${ }^{1}$

Pengertian anak sah diatur juga dalam Pasal 99 Kompilasi Hukum Islam yang menyebutkan, anak yang sah adalah:

a. Anak yang dilahirkan dalam atau akibat perkawinan yang sah

1 J. Satrio, Hukum Waris, (Bandung, Alumni, 2000), 85 
b. Hasil pembuahan suami istri yang sah di luar rahim dan dilahirkan oleh istri tersebut

Anak yang sah secara otomatis mempunyai hubungan nasab dengan ayah dan keluarga ayahnya kecuali ayah (suami dari ibu yang melahirkannya) mengingkari/ menyangkalnya, sebagaimana sabda Nabi Muhammad SAW :

$$
\begin{aligned}
& \text { عن عمرو بن شعيب عن أبيه عن جده قال: } \\
& \text { قام رجل فقال: يا رسول الله، إن فلانًا } \\
& \text { ابني، عَاهَرتُ بأمه في الجاهلية، فقال رسول } \\
& \text { الله صلى الله عليه وسلم: لا لا دعوة في } \\
& \text { الإسلام، ذهب أمر الجاهلية، الولد } \\
& \text { للفراش، وللعاهر الحجر (رواه أبو داود) }
\end{aligned}
$$

"Dari 'Amr ibn Syu'aib ra dari ayahnya dari kakeknya ia berkata: seseorang berkata: Ya Rasulullah, sesungguhnya si fulan itu anak saya, saya menzinai ibunya ketika masa jahiliyyah, Rasulullah SAW pun bersabda: "tidak ada pengakuan anak dalam Islam, telah lewat urusan di masa jahiliyyah. Anak itu adalah bagi pemilik kasur/suami dari perempuan yang melahirkan (firasy) dan bagi pezina adalah batu (dihukum)" (HR. Abu Dawud). ${ }^{2}$

Berdasarkan hadits ini, Imam Ibnu Abdi al-Bar menyatakan "Para Ulama telah sepakat, apabila ada seorang laki-laki berzina dengan perempuan yang memiliki suami kemudian melahirkan anak, maka anak tidak dinasabkan kepada laki-laki tersebut, melainkan kepada suami dari ibunya dengan ketentuan ia tidak menafikan/ mengingkari anak tersebut.

${ }^{2}$ Lihat tulisan Drs. Asrofi, SH., MH., Penetapan Asal Usul Anak dan Akibat Hukumnya Dalam Hukum Positif dalam situs Pengadilan Agama Ponorogo pada link : http://www.pa-ponorogo.go.id/berita-seputarperadilan/134-artikel/229-asal-usul-anak.

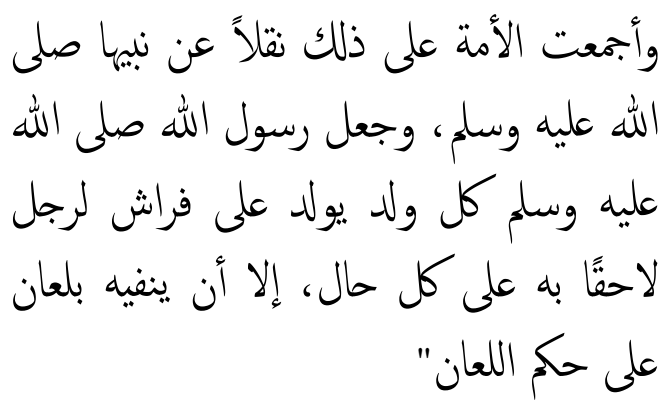

'Umat telah ijma' (bersepakat) tentang hal itu dengan dasar hadis nabi, dan Rasul SAW menetapkan setiap anak yang terlahir dari ibu yang memiliki suami, maka anak tersebut dinasabkan kepada ayahnya (suami ibunya), kecuali ia menafikan anak tersebut dengan li'an, maka hukumnya hukum li'an". 3

Anak-anak yang lahir di luar ketentuan Pasal 99 Kompilasi Hukum Islam dianggap sebagai anak luar kawin. Dalam hukum Islam anak luar kawin tidak mempunyai hubungan nasab dengan ayah biologisnya. Anak luar kawin hanya mempunyai hubungan perdata dengan ibu dan keluarga ibunya saja. Ditegaskan dalam Pasal 43 Ayat (1) Undang-undang Perkawinan No. 1 Tahun 1974 yang menyebutkan anak yang dilahirkan di luar perkawinan hanya mempunyai hubungan perdata dengan ibunya dan keluarga ibunya saja. Dalam Hukum Islam seorang anak akan dianggap sebagai anak yang sah apabila anak tersebut lahir dalam waktu 6 bulan atau 180 hari terhitung dari akad nikah kedua orang tuanya. Anak yang lahir di bawah 180 hari, maka anak tersebut dianggap sebagai anak luar kawin. Anak luar kawin dipertalikan nasabnya kepada ibunya saja dan tidak mempunyai hubungan nasab dengan ayahnya. Ditegaskan dalam Kompilasi Hukum Islam Pasal 100 yang menyebutkan "anak yang lahir di luar perkawinan hanya mempunyai hubungan nasab dengan ibunya dan keluarga ibunya". 4

Dalam hukum perdata anak yang lahir

\footnotetext{
${ }^{3}$ Imam Ibn Abdil Barr, At-Tamhid li maa fi alMuwattha min al-Ma'anii wa al-Asaanid. Pentahqiq: Usamah bin Ibrahim (Beirut: Dar al-Kutub, tt), 8, 183

${ }^{4}$ Ahmad Rafiq, Fiqih Mawaris, (Jakarta, PT. Raja Grafindo Persada, 2002), 158
} 
di luar perkawinan dinamakan natuurlijk kind (anak alami). Pendekatan istilah "anak zina" sebagai "anak yang lahir di luar perkawinan yang sah" dalam hukum Islam berbeda dengan pengertian anak zina yang dikenal dalam hukum perdata. Dalam hukum perdata, istilah anak zina adalah anak yang dilahirkan dari hubungan dua orang, laki-laki dan perempuan yang bukan suami isteri, dimana salah seorang atau kedua-duanya terikat satu perkawinan dengan orang lain. Oleh sebab itu, anak luar kawin yang dimaksud dalam hukum perdata adalah anak yang dibenihkan dan dilahirkan di luar perkawinan dan tidak diartikan sebagai anak zina. ${ }^{5}$

Sebelum ada pengakuan atau pengesahan kedua orang tuanya maka anak itu tidak sah menurut hukum. Namun apabila orang tua melakukan pengakuan atau pengesahan pada salah satu lembaga hukum, maka status anak tersebut menjadi sah.

Anak yang lahir di luar perkawinan dalam Kitab Undang-undang Hukum Perdata, meliputi : ${ }^{6}$

1) Anak Zina, adalah anak yang dilahirkan dari hubungan antara dua orang yakni laki-laki dan perempuan yang bukan suami isteri, dimana salah satu atau kedua- duanya terikat dalam suatu perkawinan dengan orang lain. Yang perlu diingat adalah bahwa salah seorang atau kedua orang tuanya yang mengadakan hubungan dan menghasilkan anak tersebut ada dalam atau masih ada dalam ikatan perkawinan dengan orang lain.

2) Anak Sumbang, adalah anak-anak

${ }^{5}$ R. Soetojo Prawirohamidjojo, Hukum Waris Kodifikasi, (Surabaya, Airlangga University Press, 2000), 16.

${ }^{6}$ R. Soetojo Prawirohamidjojo, Hukum Waris Kodifikasi, 33 yang dilahirkan dari hubungan antara dua orang yang mempunyai hubungan darah yang dekat, sehingga antara mereka dilarang oleh undang-undang untuk menikah.

3) Anak Luar Kawin yang lain, yaitu seorang anak yang lahir atau dibenihkan di luar perkawinan, namun mengenai anak yang dilahirkan sesudah ayahnya meninggal atau bercerai, belum tentu merupakan anak luar kawin karena kalau ia dibenihkan selama ibunya berada dalam perkawinan yang sah dan dilahirkan dalam jangka waktu 300 hari sesudah putusnya perkawinan, maka ia termasuk anak sah.

\section{Anak Luar Kawin dan Akibatnya dalam Pandangan Hukum Islam dan Hukum Perdata}

Hukum Islam tidak mengenal adanya pengakuan. Status anak luar kawin atau anak zina tidak bisa dirubah menjadi anak luar kawin yang diakui seperti dalam KUHPerdata. Anak luar kawin hanya bisa menuntut nafkah hidup dan biaya pendidikan. Hal ini sesuai dengan Pasal 867 Kitab Undang- undang Hukum Perdata yang berbunyi "Undang-undang memberikan kepada mereka hanya nafkah seperlunya". Status sebagai anak luar kawin menyebabkan anak luar kawin tidak bisa mendapat hak-haknya seperti anak sah. Anak yang lahir di luar perkawinan yang sah menurut ketentuan agama Islam disebut dengan anak zina (anak luar kawin). Anak zina status hukumnya hanya memiliki hubungan hukum dengan ibunya, ia tidak dinasabkan kepada bapaknya. Menentukan status anak menurut hukum Islam dapat ditelusuri melalui asal usul anak 
tersebut. Pedoman untuk menentukan sah atau tidak anak tersebut adalah jarak antara waktu perkawinan orang tua dengan waktu kelahiran anak. Batasan yang digunakan untuk menentukan status anak itu adalah akad nikahnya dan bukan perbuatan zinanya. Secara biologis (misalnya melalui tes darah) adalah bapaknya, tetapi secara hukum tidak bisa dibenarkan dan statusnya tetap sebagai anak zina. Jumhur Ulama mengatakan tenggang waktu tersebut adalah 6 bulan dihitung dari akad nikah. Bila dalam waktu kurang dari 6 bulan, kemudian wanita tersebut melahirkan, maka anak yang dilahirkan tidak bisa dihubungkan nasabnya kepada laki-laki yang menyebabkan mengandung. ${ }^{7}$

Pendapat di atas dirasakan kurang memenuhi keadilan, bila ada seorang anak lahir karena perbuatan ibu dengan bapaknya, namun hanya dipertalikan kepadanya ibunya saja meskipun perbuatan itu tanpa disadari. Menurut pertimbangan seorang ibu umumnya lebih lemah kemampuan dan keadaannya dari pada seorang bapak. Dalam kehidupan masyarakat sekarang ini banyak kaum ibu yang tidak bersuami membuang anak (bayi) yang lahir karena perzinahan. Atas dasar ini tidak adil kalau menetapkan hukum bahwa anak yang lahir karena perzinahan hanya menjadi tanggungan ibunya saja. Yang adil anak yang lahir karena perzinahan juga harus (dengan kepastian hukum) menjadi tanggung jawab bapaknya.

Batas minimal 6 bulan, sebagai penetapan pengesahan anak yang lahir sejak akad nikah pasangan suami istri, belum juga dapat menjamin kebenaran. Anak luar kawin sebagai anak yang tidak sah memiliki akibat-akibat hukum. Akibat-akibat hukum bagi anak luar kawin menurut hukum Islam antara lain: ${ }^{8}$

\footnotetext{
${ }^{7}$ Ahmad Rafiq, Fiqih Mawaris, 158.

8 www.mediamuslim.info, Status Anak Hasil Hubungan di Luar Nikah, diakses 24 November 2010).
}

1) Tidak ada hubungan nasab kepada bapaknya. Anak yang berhak dihubungkan kepada bapaknya hanya anak sah. Anak luar kawin tidak dapat dihubungkan nasabnya kepada bapaknya, melainkan hanya kepada ibunya. Secara yuridis formal bapaknya tidak wajib memberikan nafkah kepada anak luar kawin. Secara biologis ia adalah anaknya juga. Ini berarti hubungan kekerabatan hanya berlangsung secara manusiawi bukan secara hukum.

2) Tidak ada saling mewaris, sebagai akibat lebih lanjut tidak adanya hubungan antara anak dengan bapaknya. Di antara mereka tidak dapat saling mewarisi satu sama lain, karena nasab merupakan salah satu penyebab kewarisan. Keluarga bapak tidak dapat mewarisi dari anaknya tersebut.

3) Bapak tidak dapat menjadi wali bagi anak luar kawin. Jika anak tersebut kebetulan perempuan dan telah dewasa lalu akan melangsungkan pernikahan, maka bapaknya tidak berhak menjadi wali untuk anak tersebut. Wali bagi anak luar kawin perempuan yang akan melangsungkan pernikahan adalah wali hakim bukan bapak biologisnya.

Di dalam Kitab Undang-undang Hukum Perdata, ada anak luar kawin yang diakui dan anak luar kawin yang disahkan. Pengakuan merupakan perbuatan untuk meletakkan hubungan hukum antara anak dan orang tua yang mengakuinya. Pengesahan hanya terjadi dengan 
perkawinan orang tua yang telah mengakuinya lebih dahulu atau mengakuinya pada saat perkawinan dilangsungkan.

Dalam Kitab Undang-undang Hukum Perdata, ada 3 (tiga) tingkatan status hukum dari pada anak di luar perkawinan, yaitu : ${ }^{58} 9$

1. Anak di luar perkawinan yang belum diakui oleh orang tuanya.

2. Anak di luar perkawinan yang telah diakui oleh salah satu atau kedua orangtuanya.

3. Anak di luar perkawinan itu menjadi anak sah, sebagai akibat kedua orang tuanyamelangsungkan perkawinan sah. Ini berarti anak tersebut mempunyai suatu pertalian kekeluargaan dengan segala akibatnya terutama hak mawaris. Statusnya hampir sama dengan status kekeluargaan anak sah, hanya anak luar kawin tidak memiliki hubungannya dengan ayahnya. Sebaliknya, anak sah mempunyai hubungan perdata dengan ibunya dan keluarga ibunya serta hubungan perdata dengan ayahnya dan keluarga ayahnya.

\section{Pengakuan Anak Luar Kawin Dalam Hukum Perdata}

Pengakuan anak dalam literatur fiqh dikenal dengan istilah "istilhaq"atau iqraru bin nasab yang berarti pengakuan laki-laki secara suka rela terhadap seorang anak bahwa ia mempunyai hubungan darah dengan anak tersebut, baik anak tersebut di luar nikah atau anak tersebut tidak diketahui asal usulnya $^{10}$. Pengakuan anak menurut

${ }^{9}$ R. Soetojo Prawirohamidjojo, Hukum Waris Kodifikasi, 18

${ }^{10}$ Yuli Hilmasari, Pengakuan Anak Luar Kawin Dan Akibat Hukumnya Menurut Hukum Islam Dan Undang-Undang Hukum Perdata, Skripsi Sarjana
KUH Perdata terdiri atas dua jenis yaitu:

a. Pengakuan secara sukarela

Pengakuan secara sukarela ini dilakukan oleh seorang ayah atau ibu biologis anak yang lahir di luar nikah tanpa adanya paksaan dari siapapun atau bukan karena adanya putusan dari pengadilan untuk mengakui anak yang lahir diluar nikah Pengakuan anak di luar nikah dapat dianggap sah apabila dilakukan secara autentik dan tegas, tidak boleh disimpulkan. Akta autentik terhadap pengakuan anak dituangkan dalam akta notaris, akta kelahiran atau akta yang dibuat oleh pejabat Catatan Sipil dan akta pernikahan sendiri, sebagaimana yang tertuang dalam Pasal 281 KUH Perdata: "pengakuan terhadap seorang anak luar kawin, apabila yang demikian itu telah dilakukan dalam di dalam akta kelahiran si anak atau pada waktu perkawinan berlangsung, dapat dilakukan dengan tiap akta otentik"

Kita melihat di sini ada beberapa cara untuk mengakui anak luar kawin secara sukarela, yaitu:

1. Akta luar nikah

Akta ini dikeluarkan karena anak yang sebelum lahir kedua orang tuanya melangsungkan pernikahan yang sah menurut Hukum Negara. Namun tidak berarti keduanya orang tuanya tidak melangsungkan pernikahan, hanya saja pernikahan dilakukan secara hukum adat yang berlaku padanya.

Apabila anak yang lahir itu adalah anak luar kawin secara hukum maka ayahnya terputus ikatan keluarganya secara perdata terhadap anak yang dilahirkannya tersebut, Jadi hanya terikat pada ibunya saja. Akta kelahiran anak tersebut dapat di terbitkan oleh catatan sipil, dalam akta dimaksud tidak dicantumkan nama ayahnya, yang dicantumkan hanyalah nama ibunya dan nama anak yang didaftarkan

Hukum Islam Pada Fakultas Syariah dan Hukum, (Makassar, UIN Alauddin, 2014), 32 
pencatatannya $^{11}$.

2. Akta perkawinan

Hal ini berarti, bahwa laki-laki dan perempuan yang semula mengadakan hubungan di luar nikah dan kemudian menghasilkan anak luar kawin, kemudian memutuskan untuk saling menikahi secara sah sekaligus mengakui anak luar kawin, kemudian memutuskan untuk saling menikahi secara $\operatorname{sah}^{12}$. Jadi, yang diakui diatur di sini adalah pengakuan anak luar kawin yang sudah dilahirkan dan pada waktu melaporkan kelahiran, belum diberikan pengakuan oleh ayahnya. Selanjutnya maka dalam akta pernikahan diberi catatan bahwa telah lahir anak di luar nikah dan disebutkan pula nama, tempat, dan tanggal lahir si anak tersebut ${ }^{13}$

\section{Akta otentik}

Adapun akta otentik yang dimaksudkan di sini adalah akta notaris. Pengakuan dalam kata otentik perlu ditindak lanjuti dengan melaporkannya kepada Kantor Catatan Sipil di mana kelahiran anak tersebut telah didaftarkan dan minut agar pengakuan itu di catatan dalam menit akta kelahiran yang bersangkutan. Sehubungan dengan itu, Pasal 37a P.J.N menetapkan bahwa:

"Notaris wajib melaporkan tiap-tiap anak luar kawin yang dilakukan di hadapannya kepada balai harta peninggalan, dalam wilayah mana ia bertempat berkedudukan, dalam waktu 24 jam dan sekaligus memberitahukan apakah ayah atau ibu yang dilakukan oleh ayahnya terjadi sebelum atau sesudah ia meninggal”.

\footnotetext{
11 Sulaiman, Akta Luar Nikah, Akta Pengakuan Anak dan Akta Pengesahan Anak, Majalah Mimbar Hukum, Nomor 15 tahun V, Dirbinbaperais Dep. Agama, Jakarta, (2006), 20

${ }^{12}$ Peunoh Daly, Hukum Perkawinan Islam Suatu Studi Perbandingan Dalam Kalangan ahlus-Sunnah dan Negara-Negara Islam, (Jakarta: Bulan Bintang, 1988) 212

${ }_{13}$ J Satrio, Hukum Keluarga tentang Kedudukan Anak dalam Undang-Undang, (Bandung, Citra Aditya Bakti, 2005), 118
}

\section{b. Pengakuan karena Terpaksa}

Undang-undang telah memberikan pengecualian melalui pasal 287 ayat 2 KUH Perdata disebutkan: "sementara itu, apabila terjadi salah satu dari kejahatan tersebut dalam pasal 288, Pasal 294 atau pasal 322 kitab undangundang hukum pidana dan saat berlangsungnya kejahatanitu bersesuaian dengan saat kehamilan perempuan terhadap siapa kejahatan itu bersesuaian dengan saat kehamilan perempuan terhadap siapa kejahatan itu dilakukan, maka atas tuntutan mereka yang berkepentingan, boleh lah si bersalah dinyatakan sebagai bapak si anak.

\section{Kedudukan Anak Luar kawin Pasca Putusan Mahkamah Konstitusi Nomor 46/PUU- VIII/2010 Tentang Uji Materi Undang-Undang Perkawinan}

Keberadaan anak di luar kawin memiliki konsekuensi hukum tersendiri. Seorang anak luar kawin tidak memiliki hubungan hukum kekeluargaan dengan ayah atau ibunya (orang tuanya). Anak di luar kawin memang memiliki "kesamaan/kemiripan" biologis dengan kedua orang tuanya, akan tetapi secara yuridis mereka tidak memiliki hak dan kewajiban apapun terhadap anak di luar kawin tersebut. Ini artinya kedudukan seorang anak luar kawin menurut KUHPerdata tidak memiliki posisi/ikatan apapun baik secara hukum maupun biologis, dengan kata lain anak luar kawin hidup sebatang kara di muka bumi ini, sungguh menyedihkan melihat kenyataan ini anak yang merupakan ciptaan Tuhan tidak memiliki kedudukan apapun di muka bumi ini hanya karena aturan yang dibuat oleh sesamanya. ${ }^{14}$

Tentang anak di luar kawin menurut Kitab Undang-Undang Hukum Perdata (B.W.) terdapat dua jenis anak di luar

14 Satrio, Hukum Waris, (Bandung, Alumni, 1992), 153 
kawin yaitu: pertama anak zina dan kedua anak sumbang. Mengenai istilah anak yang lahir karena zina adalah anak yang dilahirkan seorang perempuan atau dibenihkan seorang laki-laki sedangkan perempuan atau laki-laki tersebut berada dalam perkawinan dengan orang lain. Sedangkan anak yang lahir dalam sumbangan adalah anak yang lahir dari seorang ibu, yang dilarang kawin menurut Undang-Undang dengan orang laki-laki yang membenihkan anak itu.

Istilah "anak luar kawin" atau "anak alami" (natuurlyke kinderen), dipergunakan dalam dua arti, yakni arti luas dan arti sempit. Dalam artian luas anak luar kawin, termasuk di dalamnya anak zina (overspelige kinderen) atau sumbang (bloedschennige kinderen) sedangkan dalam artian sempit di dalamnya tidak termasuk anak zina dan anak sumbang. ${ }^{15}$

Istilah anak luar kawin tak disebutkan dengan tegas dalam UU Perkawinan No.1 tahun 1974. Pasal 42 hanya menegaskan tentang status anak yang sah. Maka dalam konteks ini digunakan logika (argumentum a contrario) bahwa anak luar kawin adalah anak yang tidak dilahirkan dalam atau akibat perkawinan yang sah. Bagi anak yang termasuk dalam kategori anak luar kawin, sesuai Pasal 43 UU Perkawinan hanya mempunyai hubungan perdata dengan ibunya dan keluarga ibunya. Pasal ini dipertegas lagi dalam Pasal 44;

1) Seorang suami dapat menyangkal sahnya anak yang dilahirkan oleh isterinya bilamana ia dapat membuktikan bahwaisterinya telah berzina dan anak itu akibat daripada perzinahan tersebut.

2) Pengadilan memberikan keputusan tentang sah/tidaknya anak atas permintaan pihak yang

\footnotetext{
Martiman Prodjohamidjojo, Hukum Perkawinan Indonesia, (Jakarta, PT. Abadi, 2002), I, 5758
}

bersangkutan.

Berkenaan dengan pembuktian asal-usul anak, UU Perkawinan di dalam Pasal 55 menegaskan:

1. Asal-usul seorang anak hanya dapat dibuktikan dengan akte kelahiran yang autentik, yang dikeluarkan pejabat yang berwenang.

2. Bila akte kelahiran tersebut dalam ayat (1) tidak ada, pengadilan dapat mengeluarkan penetapan asal-usul seorang anak setelah diadakan pemeriksaan yang teliti berdasarkan bukti-bukti yang memenuhi syarat.

3. Atas dasar ketentuan Pengadilan tersebut ayat (2) pasal ini, maka instansi Pencatat Kelahiran yang ada dalam daerah hukum Pengadilan yang mengeluarkan akte kelahiran bagi anak yang bersangkutan.

Di dalam pasal-pasal di atas ada beberapa hal yang diatur. Pertama, anak sah adalah yang lahir dalam dan akibat perkawinan yang sah. Paling tidak ada dua bentuk kemungkinan: anak sah lahir akibat perkawinan yang sah. ${ }^{16}$ Kedua, lawan anak sah adalah anak luar perkawinan yang hanya memiliki hubungan perdata dengan ibunya. Ketiga, suami berhak melakukan pengingkaran atau penyangkalan terhadap sahnya seorang anak. Keempat, bukti asal-usul anak dapat dilakukan dengan akte kelahiran.

Terhadap anak yang awalnya luar nikah, menurut Pasal 272 KUHPerdata dapat dilakukan pengesahan dengan cara bila: ${ }^{17}$

a. Orang tuanya kawin

16 Amiur Nuruddin dan Azhari Akmal Tarigan, Hukum Perdata Islam di Indonesia, (Jakarta: Kencana, 2006)., .281-282.

${ }^{17}$ Lihat Pasal 272, 274 \& 275 KUH Perdata 
b. Sebelum mereka kawin, terlebih dahulu telah mengakui anaknya atau pengakuan tersebut dilakukan dalam akte perkawinan.

c. Adanya surat-surat pengesahan. Pengesahan dengan surat-surat pengesahan dapat dilakukan karena dua hal, yaitu:

(1) Bilamana orang tuanya lalai untuk mengakui anak-anaknya sebelum perkawinan dilangsungkan atau pada saat perkawinan dilangsungkan (Pasal 274 KUHPerdata)

(2) Bilamana terdapat masalah hubungan intergentil, misalnya sang ibu termasuk golongan Bumi Putera atau yang dapat dipersamakannya, maka terdapat alasanalasan penting menurut pertimbangan Menteri Kehakiman yang bersifat menghalang-halangi perkawinan orang tua itu.

Namun demikian, adanya pengajuan uji materiil yang dilakukan oleh Machica Muchtar ke Mahkamah Konstitusi, akhirnya merubah status anak luar kawin ini. Setelah menilai dan mengkaji fakta dan hukum (alasan pemohon berikut petitum permohonan dan setelah mendengar kesaksian para ahli dan keterangan dari pemerintah begitu juga pihak DPR-RI), maka Mahkamah Konstitusi mengabulkan permohonan para pemohon untuk sebagian. Pasal 43 ayat (1) UU No. 1 Tahun 1974 tentang Perkawinan yang menyatakan, "anak yang dilahirkan di luar perkawinan hanya mempunyai hubungan perdata dengan ibunya dan keluarga ibunya", bertentangan dengan
UUD 1945 sepanjang dimaknai menghilangkan hubungan perdata dengan laki-laki yang dapat dibuktikan berdasarkan ilmu pengetahuan dan teknologi dan/atau alat bukti lain menurut hukum ternyata mempunyai hubungan darah sebagai ayahnya.

Sementara Pasal 43 ayat (1) UU No. 1 Tahun 1974 tentang Perkawinan yang menyatakan, "anak yang dilahirkan di luar perkawinan hanya mempunyai hubungan perdata dengan ibunya dan keluarga ibunya". Dengan demikian, pasal ini tidak memiliki kekuatan hukum mengikat sepanjang dimaknai menghilangkan hubungan perdata dengan laki-laki yang dapat dibuktikan berdasarkan ilmu pengetahuan dan teknologi dan/atau alat bukti lain menurut hukum ternyata mempunyai hubungan darah sebagai ayahnya, sehingga ayat tersebut harus dibaca, "anak yang dilahirkan di luar perkawinan mempunyai hubungan perdata dengan ibunya dan keluarga ibunya serta dengan laki-laki sebagai ayahnya yang dapat dibuktikan berdasarkan ilmu pengetahuan dan teknologi dan/atau alat bukti lain menurut hukum mempunyai hubungan darah, termasuk hubungan perdata dengan keluarga ayahnya. ${ }^{18}$

Adanya putusan ini, tentu saja berdampak pada tatanan hukum perkawinan di Indonesia, khususnya mengenai kedudukan anak di luar perkawinan. Kemudian Mahkamah Konstitusi meniadakan hukum tersebut dan menciptakan hukum yang baru (constitutief), "anak yang dilahirkan di luar perkawinan mempunyai hubungan perdata dengan ibunya dan keluarga ibunya serta dengan laki-laki sebagai ayahnya yang dapat dibuktikan berdasarkan ilmu pengetahuan dan teknologi dan/atau alat bukti lain menurut hukum mempunyai hubungan darah, termasuk dengan keluarga

18 Amiur Nuruddin dan Azhari Akmal Tarigan, Hukum Perdata Islam di Indonesia, (Jakarta : Prenada Media, 2004), 216-217 
ayahnya."

Putusan ini bersifat declaratoir constitutief yang artinya menegaskan bahwa Pasal 43 ayat (1) UU No. 1 Tahun 1974 bertentangan dengan UUD 1945 dan kemudian meniadakan serta menciptakan hukum baru tentang permasalahan kedudukan anak di luar perkawinan. Penciptaan hukum baru tentang permasalahan hukum kedudukan anak di luar perkawinan memberikan payung hukum terhadap anak tersebut, sehingga kewajiban orang tua, dalam hal ini adalah bapak biologisnya, akan sampai kepada pemenuhan hak-hak anak. Keadilan yang diambil majelis hakim konstitusi dalam hal ini didasarkan pada keadilan rasional, yang mana hubungan perdata antara bapak dan anak bukan hanya dapat diwujudkan melalui hubungan perkawinan namun juga melalui hubungan darah.

Permohonan para pemohon pada intinya menganggap bahwa Undang-Undang Nomor 1 Tahun 1974 Pasal 2 ayat (2) yang menyatakan, "tiap-tiap perkawinan dicatat menurut peraturan perundangundangan yang berlaku" dan Pasal 43 ayat (1) yang menyatakan, "anak yang dilahirkan diluar perkawinan hanya mempunyai hubungan perdata dengan ibunya dan keluarga ibunya", bertentangan dengan Undang-Undang Dasar 1945 Pasal 28 B ayat (1) yang menyatakan, "setiap orang berhak membentuk keluarga dan melanjutkan keturunan melalui perkawinan yang sah" dan ayat (2) yang menyatakan, "setiap anak berhak atas kelangsungan hidup, tumbuh dan berkembang serta berhak atas perlindungan dari kekerasan dan diskriminasi", serta Pasal 28 D ayat (1) yang menyatakan, "Setiap orang berhak atas pengakuan, jaminan, perlindungan dan kepastian hukum yang adil serta perlakuan yang sama di hadapan hukum". 19

(1)
Hal pertama yang menjadi perhatian Majelis Hakim Konstitusi dalam menimbang permasalahan hukum mengenai anak yang dilahirkan di luar perkawinan adalah mengenai makna hukum (legal meaning frasa "yang dilahirkan di luar perkawinan"). Dalam kalimat selanjutnya diperoleh keterangan, "untuk memperoleh jawaban dalam prespektif yang lebih luas perlu dijawab pula permasalahan terkait, yaitu permasalahan tentang sahnya anak". Makna yang terkandung dalam frasa "yang dilahirkan di luar perkawinan", merujuk pada tentang kedudukan anak di luar perkawinan, yang pada umumnya membahas permasalahan status keperdataan anak. Pasal 42 UU Nomor 1 Tahun 1974 memberikan pengertian bahwa anak yang sah adalah anak yang dilahirkan dalam atau sebagai akibat perkawinan yang sah. Kemudian Pasal 2 ayat (1) UU No. 1 Tahun 1974 menjelaskan, bahwa "perkawinan adalah sah apabila dilakukan menurut hukum masing-masing agama dan kepercayaanya itu" dan Pasal 2 ayat (2) UU No. 1 Tahun 1974 menyatakan, "tiap-tiap perkawinan dicatat menurut peraturan perundangundangan yang berlaku."

Cita hukum yang terkandung dalam Pasal 43 ayat (1) UU No. 1 Tahun 1974, adalah berupaya untuk memberikan perlindungan hukumterhadap hak anak. Selain itu juga berupaya untuk memulihkan kerugian yang timbul dari kelahiran anak di luar perkawinan. Bahwa potensi kerugian terhadap anak dalam perkawinan yang tidak didasarkan UU No.1 Tahun 1974, adalah tidak ada pengakuan dari bapak biologisnya yang berhubungan dengan tidak dapat dituntutnya kewajiban bapak biologisnya untuk membiayai kebutuhan hidup anak dan hak-hak keperdataan lainya, serta kerugian sosial-psikologis di tengah masyarakat yang bisa berujung pada tindakan diskriminatif. Pengambilan hubungan darah sebagai patokan untuk adanya hubungan keperdataan antara anak luar kawin dengan bapakbiologisnya, 
dapat melindungi hak-hak keperdataan yang dimiliki anak tersebut. Namun kerugian sosial-psikologis yang diderita anak luar kawin tersebut belum tentu dapat dipulihkan. Harapan seorang anak yang dilahirkan di luar perkawinan, tentu saja adanya perubahan status dari tidak sah menjadi sah serta mempunyai kelengkapan keluarga, dalam artian mempunyai ayah kandung yang menjadi suami ibunya.

Dapat ditarik penjelasan bahwa dasar pertimbangan Majelis hakim Konstitusi dalam permasalahan hukum mengenai anak yang dilahirkan di luar perkawinan adalah:

1. Tidak tepat dan tidak adil manakala hukum menetapkan bahwa anak di luar perkawinan hanya memiliki hubungan dengan ibunya serta melepaskan laki-laki yang menggauli ibunya lepas dari tanggung jawab sebagai seorang bapak dan bersamaan dengan itu meniadakan hak-hak anak terhadap laki-laki tersebut sebagai bapaknya.

2. Akibat hukum dari peristiwa hukum kelahiran yang didahului hubungan seksual adalah hubungan hukum yang di dalamnya terdapat hak dan kewajiban secara bertimbal balik, yang subjek hukumnya meliputi anak, ibu dan bapak.

3. Anak yang dilahirkan harus mendapatkan perlindungan hukum, agar hak-haknya dapat terpenuhi, termasuk anak yang dilahirkan dari perkawinan yang keabsahannya masih dipersengketakan. Karena tidaklah pada tempatnya jika anak harus ikut menanggung kerugian yang ditimbulkan oleh tindakan (perkawinan) kedua orang tuanya.
Menilik persoalan pembuktian dalam Pasal 43 ayat (1) UU No. 1 Tahun 1974, untuk membuktikan keabsahan dari lakilaki yang merupakan bapak biologis dari anak luar kawin, maka dapat dibuktikan berdasarkan ilmu pengetahuan dan teknologi dan/atau alat bukti lain. Dalam hal ini yang dimaksud dengan ilmu pengetahuan dan teknologi adalah pembuktian melalui DNA.

Meskipun pada wujudnya nanti hasil tes DNA merupakan bukti tertulis yang diwujudkan dari keterangan ahli, namun eksekusi terhadap pelaksanaan tes DNA bukanlah perkara yang mudah. Masalahnya bukan pada hasil tesnya, namun pada proses pelaksanaan tes DNA, yakni kesediaan laki-laki yang diduga adalah bapak biologis untuk melaksanakan tes DNA, mengingat bahwa eksekusi terhadap badan dalam bidang perdata dalam peraturan di Indonesia belum ada, sehingga walaupun ada putusan pengadilan yang mengharuskan laki- laki yang diduga bapak biologis dari anak luar kawin untuk melaksanakan tes DNA, tetapi tidak ada peraturan yang memaksanya, maka dapat dipastikan masalah pembuktian akan berlarut-larut bahkan mungkin tidak akan pernah terbukti.

\section{Implikasi Hukum Putusan Mahkamah Konstitusi Nomor 46/PUU-VIII/2010 Terhadap Pembuatan Akta Kelahiran dan Akta Waris}

Implikasi hukum dari akibat Putusan Mahkamah Konstitusi Nomor 46/PUUVIII/2010 adalah bahwa terciptanya perlindungan hukum terhadap hak-hak anak luar nikah. Anak yang lahir dari perkawinan tidak dicatat atau anak luar nikah, harus dilindungi dengan mengajukan permohonan asal usul anak ke Pengadilan Agama. Perlindungan Hukum yang dimaksud adalah perlindungan hukum secara preventif, artinya sejak awal keberadaan janin 
anak di luar nikah itu sudah berhak untuk dirawat, dijaga dan dilindungi keberadaan sampai ia lahir kedunia. Setelah itu perlindungan refresifnya adalah mengajukan permohan ke Pengadilan mengenai asal usul anak ke Pengadilan Agama atau pengakuan anak ke Pengadilan negeri agar anak luar nikah tersebut terlindungi haknya, yakni hubungan perdata dengan ayah kandungnya.

Implikasi hukum yang lain putusan MK secara administratif anak luar nikah akan mendapatkan haknya yakni terdapatnya hubungan perdata dengan ayak kandungnya yang akan berimplikasi pada pencatuman dan ayah kandungnya pada aktakelahiran, dan ia akan mendapat hak waris juga dari ayah kandungnya, sehingga tidak ada lagi sekat antara anak sah maupun anak luar kawin.

Selain terhadap masalah administrasi, putusan MK juga berimplikasi terhadap perubahan pada sistem hukum perdata Indonesia misalnya pada sistem hukum waris. Beracuan pada Putusan Mahkamah Konstitusi Nomor 46/PUUVIII/2010 anak luar kawin dapat memperoleh warisan dari orang tuanya (bapak biologis) bila dapat membuktikan dengan ilmu pengetahuan jika anak luar kawin tersebut memiliki hubungan darah dengan bapak biologisnya, sekalipun tidak ada pengakuan dari bapak biologisnya. ${ }^{20}$

Berdasarkan beberapa pembuktian yang telah dilakukan, apabila seorang laki-laki terbukti sebagai ayah dari anak luar kawin tersebut maka pengadilan akan menetapkan bahwa anak yang dilahirkan

\footnotetext{
${ }^{20}$ Hasil Penelitian Kerjasama antara Mahkamah Konstitusi dengan Fakultas Syariah Universitas Islam Negeri Maulana Malik Ibrahim, Implementasi Putusan Mahkamah Konstitusi Nomor 46/Puu-Viii/2010 Tentang Kedudukan Anak Luar Nikah Terhadap Pembuatan Akta Kelahiran Dan Akta Waris (Studi Di Dinas Kependudukan Dan Pencatatan Sipil, Pengadilan Agama Dan Pengadilan Negeri Serta Notaris Se-Malang Raya), (Jakarta, Kepaniteraan Dan Sekretariat Jenderal Mahkamah Konstitusi , 2018), 84
}

di luar perkawinan tersebut akan mempunyai hubungan perdata dengan ibunya dan keluarga ibunya serta dengan laki-laki sebagai ayahnya yang dapat dibuktikan berdasarkan ilmu pengetahuan dan teknologi dan/ atau alat bukti lain menurut hukum mempunyai hubungan darah, termasuk hubungan perdata dengan keluarga ayahnya. Setelah pembuktian tersebut pengadilan negeri mengeluarkan penetapan yang menyatakan bahwa seorang laki-laki terbukti sebagai ayah biologis dari seorang anak luar kawin, maka pengadilan selain menunjuk instansi pencatatan kelahiran yang ada dalam daerah hukum pengadilan yang bersangkutan mengeluarkan akta kelahiran bagi anak yang bersangkutan, jugamenetapkan bahwa laki-laki tersebut berkewajiban untuk memberikan nafkah kepada si anak serta menetapkan si anak sebagai ahli waris dari laki-laki tersebut. Disinilah diperlukan peranan Notaris guna membuat akta pengakuan anak maupun dalam hal membuat surat keterangan waris. Notaris mempunyai kewenangan untuk mengurus Surat Keterangan Hak Waris (SKHW) berkaitan dengan pewarisan untuk anak luar kawin. Sama halnya dengan pembuatan akta pengakuan anak luar kawin yang telah dijelaskan di atas, untuk pengurusan SKHW berkaitan dengan pewarisan untuk anak luar kawin ini juga harus ada penetapan pengadilan yang menyatakan anak luar kawin tersebut sudah memiliki hubungan keperdataan dengan ayah biologisnya. Kewenangan lain yang dimiliki notaris adalah untuk membuat akta sehubungan dengan pewarisan tersebut. Notaris mencatatkan keinginan seorang laki-laki secara dokumen negara untuk mengakui anak luar kawin laki-laki tersebut dengan seorang wanita. Selain itu notaris juga memberikan penjelasan-penjelasan secara hukum mengenai proses pengakuan anak luar kawin sehingga para pihak mendapatkan keterangan 
sejelas-jelasnya. $^{21}$

Anak luar nikah sama haknya dibidang hukum perdata dengan anak sah, anak luar nikah harus dilindungi keberadaannya dan dipenuhi hak-haknya. Putusan MK ini sangat progresif sekali daam rangka memberikan perlindungan hukum terhadap anak, caranya adalah mengajukan permohonan asal usul anak ke Pengadian Agama. Penetapan dari Pengadilan ini akan sangat berdampak dalam banyak hal, untuk urusan administarsi kependudukan di catatan sipil dan masalah hukum perdata dalam hal mewaris dari ayah kandungnya.

Implikasi hukum putusan MK ini terhadap masalah pembagian waris, tentu ada diskriminasi lagi mengenai hak anak $^{22}{ }^{139}$. Hanya masalahnya ayah kandungnya mau bertanggung jawab apa tidak, karena masalah perdata ini, efektif atau tidaknya tergantung orangnya masing-masing. Yang jelas, anak luar nikah kedudukannya sama dengan anak sah dalam hubungan perdata dengan ayah kandungnya.

Implikasi hukum Putusan MK dalam pembuatan Akta Waris ini sangat berdampak positif dalam melindungi hak keperdataan anak luar nikah. Meskipun ia tidak mendapatkan pengakuan dari ayah kandungnya, ia akan tetap mempunyai hak waris apabila ia bisa membuktikan bahwa ia mempunyai hubungan darah dengan ayah kandungnya melalui Ilmu Pengetahuan dan teknologi (tes DNA) atau berdasarkan hukum yangberlaku. Hal ini

21 Dikta Angga Bhijana, Penerapan Putusan Mahkamah Konstitusi Nomor 46/Puu- Viii/2010 Atas Pelaksanaan Pembagian Harta Warisan Bagi Anak Luar Kawin (Studi Kasus Di Kantor Notaris Surakarta Dan Karanganyar), Privat Law Vol. IV No 1 Januari-Juni 2016, 10

${ }^{22}$ Hasil Penelitian Kerjasama antara Mahkamah Konstitusi dengan Fakultas Syariah Universitas Islam Negeri Maulana Malik Ibrahim, Implementasi Putusan Mahkamah Konstitusi Nomor 46/Puu-Viii/2010 Tentang Kedudukan Anak Luar Nikah Terhadap Pembuatan Akta Kelahiran Dan Akta Waris (Studi Di Dinas Kependudukan Dan Pencatatan Sipil, Pengadilan Agama Dan Pengadilan Negeri Serta Notaris Se-Malang Raya), 86 berarti berimplikasi terjadinya pergesaran mengenai masalah pewarisan, dimana sebelumnya anak luar nikah menurut $\mathrm{BW}$ harus ada pengakuan dari orang tuanya, sekarang dengan adanya putusan MK, tanpa adanya pengakuan anak luar nikah juga bisa mendapatkan hak-hak nya asal ia dapat membuktikan bahwa ia adalah anak kandung dari orang tuanya.

\section{Kesimpulan}

1. Berdasarkan pembahasan diatas maka dapat disimpulkan bahwa, agar anak luar kawin mempunyai hubungan keperdataan dengan kedua orang tuanya. Menurut hukum Islam anak luar kawin tidak dapat diakui sehingga anak luar kawin dalam hukum Islam hanya mempunyai hubungan keperdataan dengan ibu dan keluarga ibunya. Sedangkan dalam Kitab Undang-Undang Hukum Perdata (KUHPerdata) anak luar kawin akan mempunyai hubungan keperdataan dengan orang tuanya maka anak luar kawin harus diakui oleh ayah dan ibunya atau dengan kata lain ayah dan ibunya harus melakukan tindakan pengakuan sesuai dengan Pasal 280 KUHPerdata bahwa dengan adanya pengakuan terhadap anak luar kawin maka terlahirlah hubungan perdata antara anak dengan ayah dan ibunya.

2. Persamaan dan perbedaan status hukum anak yang dilahirkan menurut Hukum Islam dan KUHPerdata: a. Persamaan anak luar kawin antara hukum Islam dan KUHPerdata dapat dilihat dari: 1) Anak yang dilahirkan di luar perkawinan pada dasarnya 
dianggap sebagai anak yang tidak sah, 2) Anak yang dilahirkan di luar perkawinan tidak pada dasarnya tidak dapat mewaris dari ayahnya, 3) Anak luar perkawinan hanya mempunyai hubungan dengan ibunya saja. Perbedaan anak luar kawin antara hukum Islam dan KUHPerdata dapat dilihat pada: 1) Bagaimana cara menentukan atau cara dalam melakukan pengesahan anak luar kawin, dalam hal ini hukum Islam menentukan dengan syarat-syarat tertentu agar nasab anak dianggap sah, sedangkan dalam KUHPerdata dilakukan dengan cara pengesahan dan pengakuan anak luar kawin, 2) Hubungan antara ayah anak luar kawin, dalam hal ini hukum Islam hanya memberikan suatu hubungan anak luar kawin hanya dengan ibunya saja, bukan kepada ayahnya dan hubungan anak luar kawin dengan ayahnya tidak ada hubungan nasab, sedangkan dalam KUHPerdata hubungan anak luar kawin dengan ayahnya akan baru ada setelah ayahnya melakukan suatu pengakuan atau anak luar kawin tersebut diakui oleh ayah.

3. Putusan Mahkamah Konstitusi Nomor 46/PUU-VIII/2010 Tentang Kedudukan Anak Luar Kawin berimplikasi terhadap perubahan nilai-nilai dalam masyarakat mengenai status dan hak-hak anak terhadap anak luar kawin. Putusan Mahkamah Konstitusi tersebut seperti dua mata uang. Di satu sisi melindungi hak-hak anak luar kawin, karena dengan putusan tersebut maka anak luar kawin mempunyai hak untuk mewaris, mendapatkan nafkah dan perwalian dari ayah biologisnya.

4. Implikasi hukum putusan Mahkamah Konstitusi Nomor 46/PUU- VIII/2010 Tentang Kedudukan Anak Luar Kawin terhadap pembuatan Akta Kelahiran dimana Anak luar nikah dapat menuliskan lengkap nama kedua orang tuanya pada Akta Kelahirannya setelah memenuhi beberapa persyaratan. Adapun implikasi hukumnya terhadap Pembuatan Akta Waris, terjadi pergesaran yang semula menurut BW anak yang berhak mewaris adalah anak yang mendapat pengakuan dari kedua orang tuanya, setelah putusan MK bergeser bahwa anak luar nikah tanpa pengakuan orang tuanya bisajuga menerima hak waris asal anak luar nikah tersebut dapat membuktikan bahwa ia adalah anak kandung dari laki-laki tersebut dengan menggunkan Ilmu Pengetahuan dan teknologi serta berdasarkan hukum yang berlaku.

\section{DAFTAR PUSTAKA}

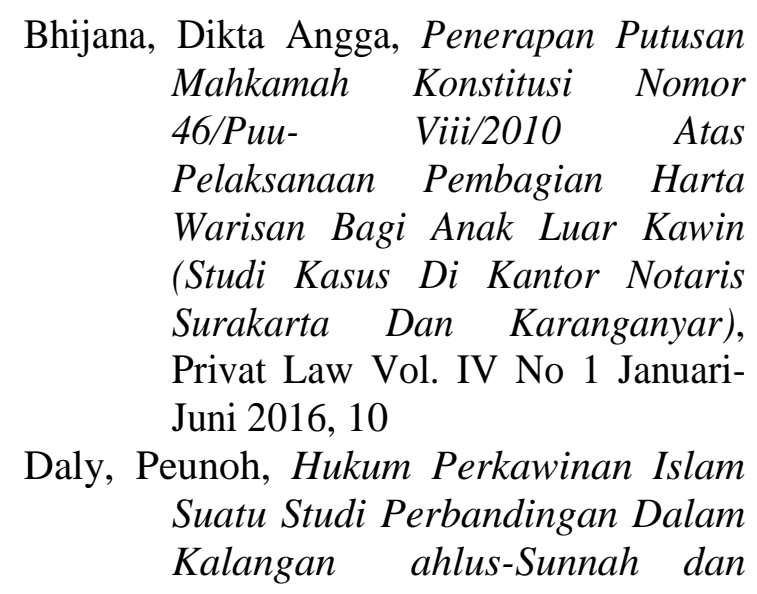


Negara-Negara Islam, Jakarta: Bulan Bintang, 1988.

Asrofi, Penetapan Asal Usul Anak dan Akibat Hukumnya Dalam Hukum Positif dalam situs Pengadilan Agama Ponorogo pada link : http://www.pa-

ponorogo.go.id/berita-seputarperadilan/134-artikel/229-asalusul-anak.

Hasil Penelitian Kerjasama antara Mahkamah Konstitusi dengan Fakultas Syariah Universitas Islam Negeri Maulana Malik Ibrahim, Implementasi Putusan Mahkamah Konstitusi Nomor 46/Puu-Viii/2010 Tentang Kedudukan Anak Luar Nikah Terhadap Pembuatan Akta Kelahiran Dan Akta Waris (Studi Di Dinas Kependudukan Dan Pencatatan Sipil, Pengadilan Agama Dan Pengadilan Negeri Serta Notaris Se-Malang Raya), Jakarta, Kepaniteraan Dan Sekretariat Jenderal Mahkamah Konstitusi , 2018

Hilmasari, Yuli , Pengakuan Anak Luar Kawin Dan Akibat Hukumnya Menurut Hukum Islam Dan Undang-Undang Hukum Perdata, Skripsi Sarjana Hukum Islam Pada Fakultas Syariah dan Hukum, UIN Alauddin, Makassar, 2014.

Ibn Abdil Barr, Imam, At-Tamhid li maa fi al-Muwattha min al-Ma'anii wa al-Asaanid. Pentahqiq: Usamah bin Ibrahim. Beirut: Dar alKutub, Juz 8, tt.

J. Satrio, 2000, Hukum Waris, Alumni, Bandung.

J. Satrio, Hukum Keluarga tentang Kedudukan Anak dalam UndangUndang, Citra Aditya Bakti, Bandung, 2005

Media Muslim, 2007, Status Anak Hasil Hubungan di Luar Nikah, www.mediamuslim.info, diakses 24 November 2010.
Nuruddin , Amiur dan Tarigan, Azhari Akmal, Hukum Perdata Islam di Indonesia, Jakarta: Kencana, 2006.

Prawirohamidjojo, R. Soetojo, Hukum Waris Kodifikasi, Airlangga University Press,Surabaya, 2000.

Prodjohamidjojo, Martiman, Hukum Perkawinan Indonesia, PT. Abadi, Cet. I, Jakarta, 2002.

Rafiq, Ahmad, 2002, Fiqih Mawaris, Jakarta, PT. Raja Grafindo Persada.

Sulaiman, Akta Luar Nikah, Akta Pengakuan Anak dan Akta Pengesahan Anak, Majalah Mimbar Hukum, Nomor 15 tahun V, Dirbinbaperais Dep. Agama, Jakarta. 